\title{
英国レッチワースにおける住環境管理についての居住者評価 EVALUATION OF RESIDENTS ON MANAGEMENT SYSTEM OF LIVING ENVIRONMENT AT LETCHWORTH GARDEN CITY
}

\author{
齊藤広子*
}

Hiroko SAITO

\begin{abstract}
This study examines the roles of local property management organization at Letchworth Garden City in the UK. Its objective is to learn essence of the management system of living environment by local property management organization that may be applicable to Japan. In this regard, the study is carried out to clarify residents' evaluation on living environment and the property management organization at the housing area via the case study at Letchworth Garden City.

The study found that the residents tended to positively evaluate the activities of the organization for maintaining landscape and living environment. It implies that establishment of the management system is important for Japan, in which the management organization has a right to control the use of lands in the area in order to make the area more beautiful, valuable and democratic.
\end{abstract}

Keywords : Detached housing area, Management, Garden city, Living environment, Property management 戸建て住宅地管理田園都市、住環境管理

\section{1. 研究の背景之目的}

\section{・住宅地経営としての住環境管理の必要性}

住環境管理として、従来から、第一に生活管理機能、第二に空間 管理機能、第三に行政との協働機能、第四に利害調整機能、第五に 利便性向上機能が求められていた。この分け方は、対象空間の利用者 と、行為の側面を考慮したものである生 1)。具体的には、生活管理機 能とは地域の防災、防犯、助け合い、近隣トラブルの予防·解消、教 育機能である。空間管理機能とは、共用施設・共用空間の維持管理・ 運営管理である。行政との協働機能とは、公共空間の維持管理・運 営管理や改善を行政と協働して行うことである。利害調整機能とは、 個々の敷地（私有空間）の土地利用に関する個別の利害を調整し、 より質の高い住環境をつくる機能である。利便性向上機能とは、快 適で居住性・利便性の高い生活実現にサービスや施設の提供である。

人口減少・少子高齢化時代には、地域に根ざした住環境管理の必 要性が高まる。それは地域の住環境管理上の要求が多様化するとと もに、他住宅地との差別化から、より豊かなコモンスペースをもつ 住宅地の増加（上記の第二機能の強化）、より質の高い住環境の維持 (第四機能の強化)、それを行政の財政負担・各家庭の財政負担を増 加しない形で実現することが求められる（第三. 五機能の強化）。さ らに、空き地・空き家の增加に対応する、防犯・防災体制の強化（第 一機能）や高齢者居住支援強化（第一.第五機能の強化）が必要であ る。これは、個人や家族（私）と行政（公）、そして行政（官）と民 間（民）のあらたな役割分担とそれを補完する地域のコモンパワー 強化の必要性である。地域に根ざしたものを、地域の実情を踏まえ、 地域で実践する「地域力」を強化する体制が必要である。

この体制には、第一に 5 機能を地域で総合的に取組むことが必要
である。つまり、これらの機能強化の必要性は、単なる各機能低下 の補完体制を求めているのではなく、<個人・行政・市場〉による 体制の限界と、それに替わる新たな体制の必要性を示唆しているか らである(図 1)。第二に、実行には地域が経済力をつけることが必 要である。住環境管理が住宅所有者・利用者から支払われる管理費の みで運営される場合は、財政基盤が弱く、時代の変化に対応した組織 体制・専門家の雇用・サービスの提供、空間変更を円滑に実施でき ないからである。そこで地域で住環境管理の必要な行為を適正に実 施するには、そのための費用を地域自らが生出すことが必要となる。

そこで考えるべきことは、地域力を強化するために、どのような 体制が必要か。また、その体制を維持するために、どのように経済 的基盤を持ち、住環境管理を実践し、地域を経営するのかである。

従来から、建築学・都市計画分野で住環境管理のあり方の検討が 行われているが、それは利害調整機能や行政との協働機能を中心と したもので、住環境管理を総合的にとらえ、かつ地域の経営という視 点を含んでの研究が行われてきていない。しかし、地域力の強化は、 総合的に持続性のある形を、目指す必要がある。ゆえに、経済基盤 をどこに置くかは、重要な課題である。これは、いいかえると、都 市経営と結びついた住宅地経営の視点の必要性である。

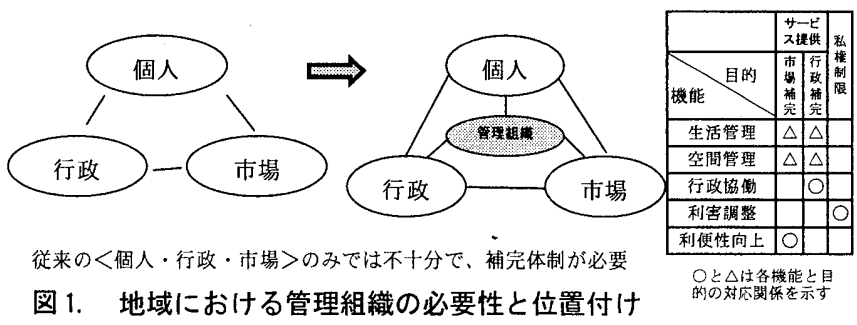

\footnotetext{
* 明海大学不動産学部不動産学科 教授・学博 Prof., Faculty of Real Estate Sciences, Meikai Univ., Ph. D.
} 
本研究では、住宅地経営の視点から、住睘境管理体制のあり方を 検討する。具体的にはどのような組織が何を行い、また、組織運営 のためにどのような体制をつくり、経営を維持するのかを考察する。

\section{- 既往研究と本研究の位置付け-研究の目的-}

住宅地における総合的に住環境管理を行う主体として、日本では マンション（区分所有の共同住宅）の管理組合、戸建住宅地の管理 組織、諸外国では、郊外型ではアメリカのHOA注 2) (homeowners association : 管理組合)、英国のレッチワース財団注3) 等がある。

既往研究によると、第一〜第五の機能を包括する住環境管理方式 として大きく二つの方式がみられる。第一は、米国のHOAやわが国 のマンション管理組合に代表される「住民主体型」である。第二は、 住民組織を特に結成せず、住民の意向を踏まえて専門の管理会社が 運営する「専門会社型」である。

日本では、マンション（区分所有共同住宅）の管理方法は不動産 所有者（建物の区分所有者）全員参加の「住民主体型」である。主 に空間管理機能と利害調整機能をもち、区分所有者全員による費用 負担で運営される。しかし、所有者の高龄化、空き家化が進行する と、管理組合の経済的基盤が低下するという問題が生じている。そ こで経済的基盤や経営能力を高めるために、管理者方式の導入や管 理組合が駐車場や店舗部分を共用部分として所有し、賃貸料により 収益を得る等の取組みが見られるようになっている。コモンスペー スがある、あるいはコモン施設がある戸建て住宅地等においては「住 民主体型」「専門会社型」両タイプが見られるが、組織結成の法的根 拠や機能が明確でないために、入居後に消减する傾向もみられる壮 4)。

米国では、マンション、戸建て住宅地、またこれらの混合住宅地の 場合には、住宅所有者全員によってHOAが組織される。つまり、住 民主体型である。HOAは、空間管理機能と利害調整機能を主とし、 レクレーションの提供など（利便性向上機能）による他の住宅地と の差別化や行政との住環境管理の役割分担の協議（行政との協働機 能）を行う。管理組織が主となり管理を行うが、管理行為の量と質 により、管理会社に委託をするケースが多い。管理会社は委託され た業務を執行する。組織運営と管理会社への委託も含めて管理のた めの費用は不動産所有者（主に住宅所有者）が負担する。

こうして、日本、米国ともに組織の活動自らで費用を生出すよう な経済的基盤を持たないケースが多い住り。

英国では、レッチワースを含む、ガーデンシティ、ガーデンサバ 一ブ、ガーデンビレッジの住環境管理方法には、一つには 5 機能 (生 活管理機能、空間管理機能、行政との協㗢機能、利害調整機能、利 便性向上機能）の全てを実施する総合タイプと、もう一つは利害調 整機能が主となる限定的なタイプがある壮 6)。機能が総合的な前者の タイプに注目すると、専門の管理組織が設定され、組織が利害調整機 能として私権をコントロールする権限をもつ。このタイプは、会員か らの管理費が主な収入ではなく、組織自らが不動産を所有し、経営 するという経済的基盤がある。組織の構成員は居住者に限定されて いない。専門会社が住民の意見を聞きながら運営する「専門会社型」 である。事例としては、工場主による社宅として作られたガーデン ビレッジのポートサンライト、ボーンビル、ニューアースウイック と、レッチワースガーデンシティがある。ボーンビルとニューアー スウイックの管理組織は、ハウジングアソシエーションであり、単 一の住宅地のみを管理しているわけではなく、住宅地ごとの独立採
算ではない。また、ポートサンライトの管理組織は約 3 割が親会社 からの収入で経営が成り立っており、独立した経営状態ではない。 経済的基盤を持ち、一定の地域に限定した形で、住環境管理を行っ ている事例は、レッチワースガーデンシティである（表 1)。

そこで、本研究では、住環境管理を総合的に行い、かつ「住民組 織を結成せず、住民の意向を踏まえて専門の管理会社が運営する方 式」である専門会社型として、英国レッチワースガーデンシティに 注目する。当住宅地を住宅地経営の視点から住環境管理方法を分析 し、わが国の参考とするには、以下の点を明らかにする必要がある。

第一に、住環境管理方法の実態とそれを可能とする住宅地経営の 実態（財政分析）である。第二に、住環境管理方法に対する居住者 の評価である。第一については、関連する既往研究がある注 7)。本研 究ではこれらの研究成果を踏まえて、管理方法の現状を明らかにす る。第二については、レッチワースガーデンシティ居住者へのアン ケート調査から明らかにする。

つまり、本研究の目的は、わが国における住宅地の住宅地経営の 視点を持った住環境管理の方法を考察するために、英国レッチワー スガーデンシティの住環境管理とそれを支える経済的基盤と、それ に対する居住者の評価を明らかにすることにある。

表 1. HOA 方式<米国〉とレッチワース方式<英国>の機能の相違

\begin{tabular}{|c|c|c|c|c|c|c|c|}
\hline & 方式 & $\begin{array}{l}\text { 生活 } \\
\text { 管 } \\
\text { 理 }\end{array}$ & $\begin{array}{l}\text { 闠 } \\
\text { 管理 }\end{array}$ & $\begin{array}{l}\text { 行 } \\
\text { 政 } \\
\text { 染働 }\end{array}$ & $\begin{array}{l}\text { 梨 } \\
\text { 害 } \\
\text { 調整 }\end{array}$ & $\begin{array}{l}\text { 利便的 } \\
\text { 性 } \\
\text { 向 }\end{array}$ & $\begin{array}{l}\text { 運営のための } \\
\text { な収入 }\end{array}$ \\
\hline 来国 $\mathrm{HOA}$ & 住民王体型 & $\triangle$ & (c) & 0 & (c) & $\Delta$ & 管理賈 \\
\hline 英国 & 真門会社型 & $\overline{0}$ & (ब) & O & (c) & 0 & 不動産経営 \\
\hline 日本マンション & 住民主体型 & $\triangle$ & (a) & $x$ & 0 & $\Delta$ & 營理費 \\
\hline 日本戸建倠宅 & 住民主体型 & $\triangle$ & $\triangle$ & $\Delta$ & $\triangle$ & $\triangle$ & 管理費 \\
\hline 地及飞猩合住宅地 & 専門会社型 & x & $\triangle$ & $\bar{x}$ & $x$ & $\triangle$ & 管理費 \\
\hline
\end{tabular}

\section{2. 研究の方法}

\section{・調査対象住宅地の位置付けと概要}

英国のガーデンビレッジ、ガーデンシティ、ガーデンサバーブの 管理組織で、レッチワースのように総合的に住環境管理を行うタイ プには、次のような共通点がある。

豊かな共用施設を組織が所有、管理し、その延長として公共空間 の維持管理を行うている。また、組織が不動産を所有·経営している ことから、時代の変化に対応した地域需要に応じた施設を提供でき る。不動産経営が経済的基盤となることから、専任のスタッフや専 門家の雇用が可能となり、活動範囲は地域住民個人では解決困難な 問題の予防·解決に向けて広がり、多様な取組みが行われている。

その代表的な例としてレッチワースガーデンシティがある。レッ チワースガーデンシティは 1905 年から入居が始まり、ハワードのガ 一デンシティ (田園都市) 構想に基づき、土地を切り売りするので はなく、リースホールド注 8) で街がつくられてきた。その土地を所有 するのが、当初は田園都市株式会社、公社、そして1995 年からはレ ッチワースガーデンシティヘリテージ財団である。

現在、5500 エーカーの土地（当初 3818 エ一カーから拡大）の $45 \%$ が居住用に利用され、14000世帯、33000 人が居住、戸建て住宅、2 戸 1 住宅、長屋建て、共同住宅がある。

ポートサンライトのようなガーデンビレッジ、レッチワース・ウ エルウインのガーデンシティも共にリースホールドで街が作られて きた。1967 年の法律（1967 年法 Leasehold ReformAct 1967）で は、リースホールドにより戸建て住宅を保有している人たちに、フ 
リーホールドを買う権利を与えること、あるいはリースホールド権 を保有するものに対して、リースの期間が満了した場合には、借主 に 1 回の更新権として 50 年間の契約の延長をつける権利を与えた。 1993 年法 (Leasehold Reform、Housing and urban Development Act 1993) では、契約満了前でも借主が 90 年間の契約延長ができる権利 を与えた。結果、英国では住宅の多くはリースホールドからフリー ホールドに転換しつつあり、レッチワースでも約半数がリースホー ルドからフリーホールドへと変っている。レッチワースでは 3 年間 住めばフリーホールドへ移行する権利が得られる注9)。

尚、ウエルウィンガーデンシティはニュータウン法成立時に公共 空間等が行政に全て移管され、住宅地経営を行う管理組織は現在な W。

\section{、調查方法}

2005 年 3 月から 2006 年 2 月まで、現地の管理組織の担当者、行 政担当者にヒヤリング調查及び資料収集を実施した。さらに、居住 者アンケート調査（チープコテッジ地区とその隣接地区を対象 ; 図 2)を実施した。居住者アンケート調查は、直接配付留置き自記入後、 郵送回収する方法で 2006 年 2 月〜 3 月に実施した。配付数 300 、回 収数 167 、有効回収数は 165 で、回収率は $55.0 \%$ である。

対象地区として、チープコテッジ地区と、それに隣接する地区を 選んだ。その理由は、チープコテッジ地区はレッチワースの戸建て住 宅地区のなかで敷地面積が狭い注 10)ことから日本と同様の住環境管 理問題が生じやすいこと等を考慮し、選定した。しかし、当地区は保 全地区であり、100 年以上経過した住宅が多く、また住宅は 1905 年 にチープコテッジ展示会の作品であることから、住環境に強い関心 をもつ居住者が多くなり、レッチワース全体の居住者の傾向を示す ものではない可能 性がある。そこで、 入居時期が異なり、 レッチワース住宅 地としては一般的 な戸建て住宅地で ある隣接地区も含 めて対象地区とし た。



図 2. 調查対象地区

\section{3. 調查対象住宅地レッチワースの住宅地経営方法 3.1 組織の変遷 (表 2)}

ハワードの思想に基づき、第一田園都市株式会社がレッチワース の土地を所有する。会社は株保有による利益配当を制限し、余剩金 を街の改良や住民生活向上へと地域に還元する民間の非営利の会社 であった ${ }^{14)}$ 。しかし、会社が大きく利益を上げることが可能となり、 1956 年には総会で配当率の制限の撤廃を決め ${ }^{4)}$ 、1960 年には、会社 の乗っ取りが企てられた。そこで、ハワードの精神を守るために住 民による「ガーデンシティを守れ」運動が行わ机、その成果として 公社法が成立し、公社として開発・経営・管理運営を行うことにな つた注 11)。

さらに、英国の民営化の動きから、公社は1995 年に全財産の管理 を、レッチワースガーデンシティヘリテージ財団（以下、財団とよ ぶ）に引き継がれることになる住 12)。
このように管理組織は、時代の変化のなかで、主体が民 $\Rightarrow$ 公 $\Rightarrow$ 民 と変りつつも、ハワードの思想をうけつぎ、住宅地の管理運営のた めに 100 年以上もつづいている。

表 2.レッチワースの開発と管理の主な内容

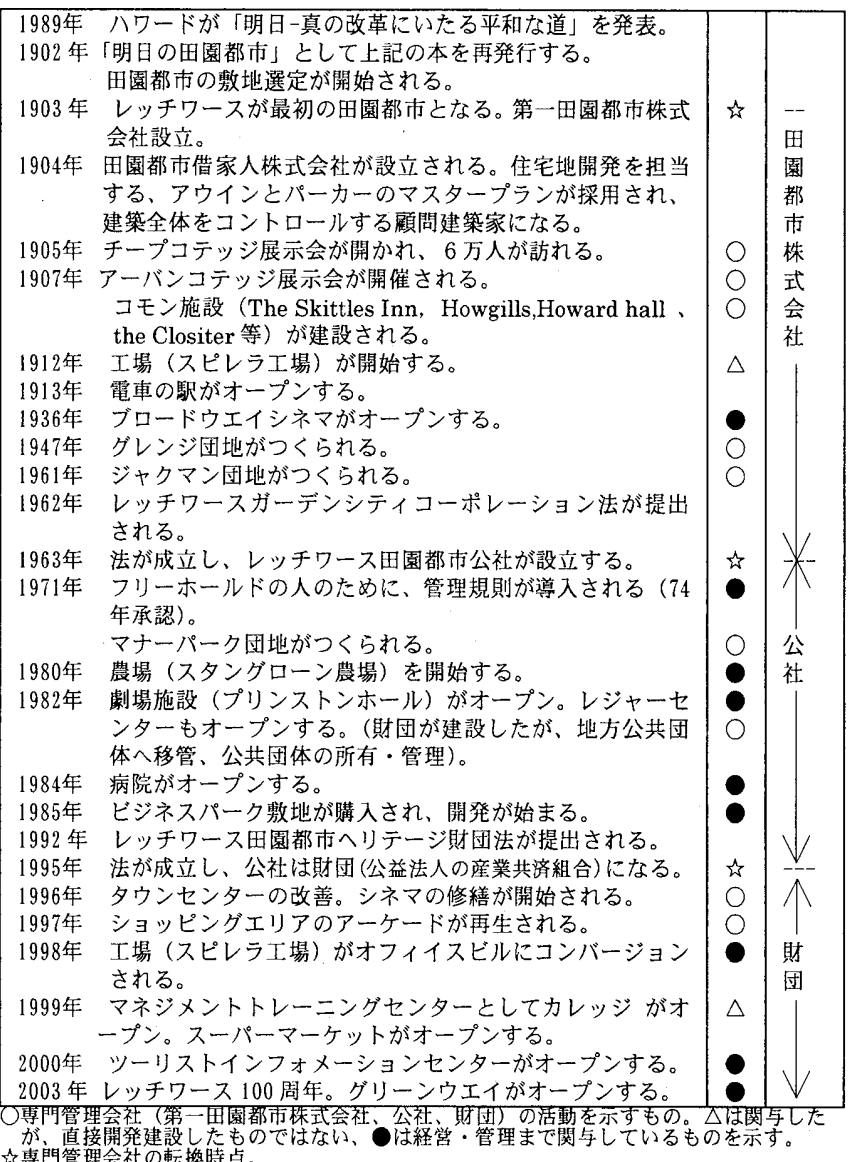

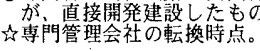

\section{2 財団の組織体制 \\ (1)組織体制}

財団はレッチワースガーデンシティヘリテージ財団法(1995 年) 注 13)に基づく組織（1965 年産業共済組合法を根拠にした慈善団体資格 を持つ）である。目的は、ガーデンシティがつくられた趣旨にのつ とった事業全体の推進にある(1995 年法第 4 条)。具体的には、(1)歴 史性のある、あるいは美しい建物の保全、(2)社会福祉と地域コミュ ニティのためのレジャーやレクレーション施設供給、(3)教育・学習、 (4)貧困や病気の予防・解消、(5)地域組織活動の支援等の促進である。

業務遂行のために、職員が常勤専任で 156 名いる。多様な事業を 実施しているので、多様な職能の人が必要となる。部門でみると、 コミュニティへの還元事業（Charitable）担当 57 名、映画館担当 20 名、メンテナンス担当 39 名、農業担当 9 名、運営 (Administration) 担当 25 名、マーケーティング 担当 6 名である注 14 。このうち居住 者は 37 名であるが、居住者だから雇用されているわけではない。 また、この他に五つの別会社をもつ注 15 )。

居住者の意向を財団運営に反映するのは、ガバナーである。ガバ ナーが組織の重要な方針を決める。30名のガバナーは三つのルール に基づいて選出される註16)。(1)居住者から選挙で6人が選ばれる。 (2) 8 人は地元のクラブ住 17) 等から推薦され、 2 人は地方行政の担当 者である(Hertfordshire Country Council と North Hertfordshire 
District Council から各 1名)。(3)14 人は運営委員会から指名される。 こうして居住者代表をガバナ一とする。ガバナーは 1 年に 5 回、 4 回の集会と居住者総会に出席するが、全員報酬や給与はない。

\section{(2)組織の運営}

年次総会で運営委員として、8 名のガバナーが選出され、運営委員 会を構成する。規定注 18)（財団ルールの 36a）に基づき、運営委員 は每年 3 分の 1 が入れ替わる注 ${ }^{19}$ )。運営委員会が組織の方針決定機 関となる。運営委員会が事務局長を指名し、事務局長が 3 名の担当 部長を任命する。事務局長と担当部長の合計 4 名が骨格となり、156 名の職員で組織の運営と事業を行う。

居住者も含めた集会を開く。集会は年 4 回である。 3 月に総会、 9 月に次年度の計画のための集会である。さらに、12 月と 6 月にも 集会を開催する。居住者は 5 月に行う居住者総会に参加する。年次 決算と予算の報告が行われる。このように、財団は活動方針や財政 状況を居住者に公開する。毎年の財政状況を示したものと活動結果 を示したパンフレットは 14000 世帯全戸に配付される。

こうしたガバナーの多数を居住者から選出すること、年次総会を 開き、財政状況を全居住者に報告することは公社から財団への移行 時の下院特別委員会による決定事項である註 20。

\section{(3)組織の財源}

管理組織である財団は、住宅地の住環境管理を実践するために、住 宅地の居住者や地域の不動産所有者から管理費を徴集していない。

表 3. 財政基盤（総収入と総支出） 金額ポンド

\begin{tabular}{|c|c|c|c|c|c|c|}
\hline & \multicolumn{2}{|c|}{2002 年 } & \multicolumn{2}{|c|}{2003 年 } & \multicolumn{2}{|c|}{2004 年 } \\
\hline 総收入 & 9202000 & $100 \%$ & 9235000 & $100 \%$ & 9494000 & $100 \%$ \\
\hline 不動珄取入 & 66990000 & 72.8 & 6711000 & 72.7 & 6748000 & 71.1 \\
\hline 事業收入と販売益 & 551000 & 6.0 & 617000 & 6.7 & 613000 & 7.1 \\
\hline 農場収入 & 703000 & 7.6 & 708000 & 7.7 & 771000 & 8.1 \\
\hline 教育農場収入 & 234000 & 2.5 & 242000 & 2.6 & 241000 & 2.5 \\
\hline 映画館收入 & 746000 & 8.1 & 638000 & 6.9 & 670000 & 7.1 \\
\hline 他のコミュニティ還元活動収入 & 115000 & 1.2 & 118000 & 1.3 & 109000 & 1.1 \\
\hline 投資収入と利益 & 154000 & 1.7 & 201000 & 2.2 & 342000 & 3.6 \\
\hline 総支出 & 9081000 & $100 \%$ & 9210000 & $100 \%$ & 9322000 & $100 \%$ \\
\hline 不動産関運支出 & 2694000 & 29.7 & 2899000 & 31.5 & 2740000 & 29.4 \\
\hline 事業と小売関係 & 722000 & 8.0 & 704000 & 7.6 & 639000 & 6.9 \\
\hline 農場コスト & 542000 & 6.0 & 493000 & 5.4 & 594000 & 6.3 \\
\hline 教育蕽場コスト & 230000 & 2.5 & 240000 & 2.6 & 190000 & 2.0 \\
\hline 映画館コスト & 696000 & 7.7 & 649000 & 7.0 & 728000 & 7.8 \\
\hline 一他のコミュニティ適元活動収出 & 1109000 & 12.2 & 1464000 & 15.9 & 1392000 & 14.9 \\
\hline クラフ等への補助金 & 428000 & 4.7 & 211000 & 2.3 & 334000 & 3.6 \\
\hline 運営費（人件費なと） & 2079000 & 22.9 & 2205000 & 23.9 & 2339000 & 25.1 \\
\hline 支払利息 & 581000 & 6.4 & 345000 & 3.7 & 366000 & 3.9 \\
\hline \multirow[t]{3}{*}{ 表 4 . } & & & & & 額ポンド & \\
\hline & \multicolumn{2}{|c|}{2002 年 } & \multicolumn{2}{|c|}{2003 年 } & \multicolumn{2}{|c|}{ 2004年 } \\
\hline & 1109000 & $100 \%$ & 1464000 & $100 \%$ & 1392000 & $100 \%$ \\
\hline 病院（ティホスピタル） & 242000 & 21.8 & 251000 & 17.1 & 258000 & 18.5 \\
\hline ミニバス & 58000 & 5.2 & 65000 & 4.4 & 64000 & 4.6 \\
\hline ヘリテージ博物館 & 150000 & 13.5 & 174000 & 11.9 & 167000 & 12.0 \\
\hline ホール & 403000 & 36.3 & 482000 & 32.9 & 518000 & 37.2 \\
\hline 100年記念イベント & - & - & 161000 & 11.0 & 24000 & 1.7 \\
\hline コミュニティ情報提供 & 48000 & 4.3 & 49000 & 3.3 & 48000 & 3.4 \\
\hline 夢璄改善 (CCTV、植栽管理等) & 156000 & 14.0 & 195000 & 13.3 & 230000 & 16.5 \\
\hline その他 & 52000 & 4.7 & 87000 & 5.9 & 83000 & 6.0 \\
\hline
\end{tabular}

管理組織活動費用は保有不動産の賃貸料が収入の約 7 割を占め、 ホールの使用料や物品販売等が $7.1 \%$ 、その他保有・経営する農場、 映画館等からの収入である（表 3）。これらの収入の他に、報酬のな いガバナーの人的資源も投下されている。一方、支出(2004 年度)は、 保有不動産運用に $29.4 \%$ 、ホールでの物品販壳等に $6.9 \%$ 、職員の 人件費等（主に第二〜四機能担当）の運営費が $25.1 \%$ 、支払利息が $3.9 \%$ 、残り $34.7 \%$ がコュニティへの還元事業として、農場や映画 館の経営、バスの運行等、居住者へサービスや施設の提供(主に第一. 五機能)等に充てられる(表 4)。

\section{3 財団の活動 一住環境管理の取組み一}

財団の活動として、住環境管理の 5 機能に分けてみる。

(1) 空間管理機能<第二機能>

レッチワースでは、財団が住宅、商業施設、コミュニティ施設、宅 地などを開発し、それらは行政に移管するもの、民間企業に譲渡する もの、個人に譲渡するもの、自ら所有し管理するものがある。

公園は基本的に行政に移管している。ゆえに、地方公共団体が管 理する。道路は、幹線道路は国が所有している。それ以外の道路は 地方公共団体が所有する場合と財団が所有する場合がある。財団が 所有する道路は、財団が維持管理をする。その場合の街路樹の剪定 も財団の仕事になる。

そのほか、工業関倸 (約 200 ユニット) や事務所不動産 (200.000 $\mathrm{f} 2)$ 、住宅 $(400 \sim 500$ 戸)、小売店舗（120 区画）、コミュニティ施 設を所有、管理・経営をする。

コミュニティ施設は、財団が所有するものとして、プレイグラン ド、グランド、プランテーション、コモングリン・グリーンスペー ス、ゴルフコース、テニスコート、プール、ボーリング場、池、コ ミュニティセンター、博物館、ホール、農場、病院、ツーリストセ ンター、スピレラ（オフィス、会議室、結婚式場等）がある。原則 これらは財団が管理・運営する。例外として、テニスコートはテニ スクラブが経営し、プレイグランド、プール、ボーリング場、池は行 政が管理をする。このほかに、クリケット場があるが、これはクリ ケットクラブが所有し、管理をする。住宅地を取り巻く、緑道くグ リーンウエイ>の 13.6 マイルは、財団の所有・管理である。

財団は、公共空間を原則行政に移管する。そして所有にかかわらず、 行政そ協議の上で維持管理を担当する。コミュニティ施設も公共性 のあるものは行政による管理を促し、その他は自ら所有し、管理・経 営する。それはコミュニティへの利益の還元を目指しており、営利目 的の経営にならないためである注 21)。その他、住宅地のなかの必要な 施設の建設や再開発も行う注 22 。再開発事業に必要な費用を行政か らの補助金も含めて集め、共同事業者を探し出し、事業を実施する。

\section{(2)行政との協働機能<第三機能>}

財団之行政は公共空間の維持管理を協議し、道路やコミュニティ 施設の維持管理の役割分担をしている。近年、地元行政の財政力が 低下し、財団が費用を負担し、修繥する箇所が堌えている。例え財 団が地域の公共空間の維持管理を行っても、住民が負担すべき税(住 民税や固定資産税等）が低減するといった、住宅地経営と都市経営 の連動はみられず、財団の財政負担を増やす結果となる。

\section{(3)利害調整自治機能 $<$ 第四機能 $>$}

財団は、住宅の修繥や増改築などをコントロールする。レッチワ 一スは当初の住宅の保有はリースホールドであうたために、各住宅 の修繥や増改勧に関するルールをカベナントで位置付けて契約を行 っていた。カベナントとは、リースホールドで不動産を賃貸借する 際に付随する条件である。カベナントの内容をフリーホールドにな つても承継する方法として 1967 年法を根拠法として管理規則が制 定された注 ${ }^{23)}$ 。ゆえに、リースホールドの場合はカベナントで、フリ 一ホールドの場合は管理規則で、財団は住宅の修繥や増改築などを コントロールする権限をもつ。実際に、レッチワースでは、不動産所 有者が建物の修繥や改築する際には、行政への申請と許可、さらに 財団への申請と許可の両方が必要となる。二つは独立して行われて 
いる。つまり、行政とは別に、財団独自の活動で住環境の質が高まる ように規制 (以下 A. B.C) を行い, 誘導 (以下 D.E)も実施している。 A. 管理規則

管理規則の主な内容は、表 5 である。建物を適正に維持管理する 必要があること、それが適正に行われない場合には財団に強制執行 権があること、また、建物の修繥や改筑には財団への申請と許可が 必要であることが示されている注 24)。

B. デザインガイダンス

財団が申請を許可するか否かは、財団が作成したデザインガイダ ンスに基づくことになる。デザインガイダンスの内容は表 6 である。

\section{表 5. レッチワースの管理規則の主な内容}

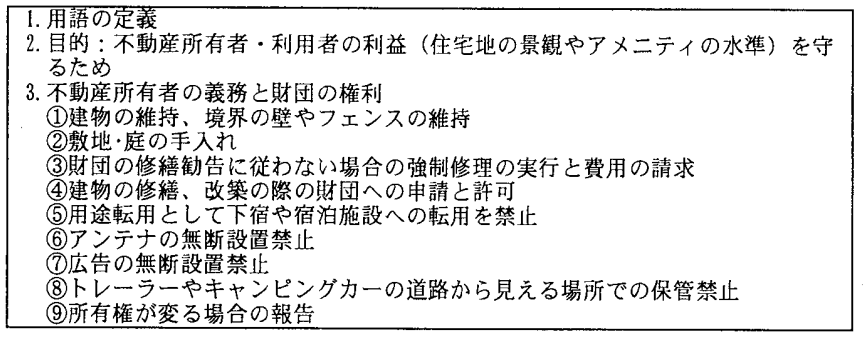

\section{表 6. デザインガイダンスの主な内容 ２004年デザインガイダンス}

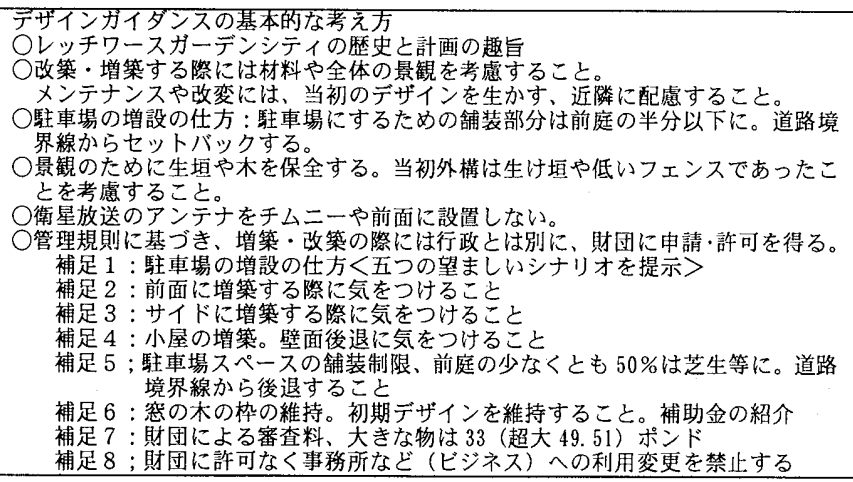

表 7. 財団への修繥などの申請と許可件数

\begin{tabular}{|c|c|c|}
\hline 年度 & 申請数 & 評可率（申請に咐して許可した割合） \\
\hline 2004 & 886 & $98 \%$ \\
\hline 2003 & 784 & $96 \%$ \\
\hline 2002 & 711 & 不明 \\
\hline
\end{tabular}

表 8. 修繥のための補助金の交付件数と総額 : 金額ポンド

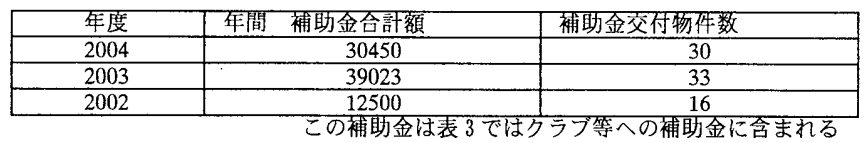

具体的な数字によって住環境のあるべき姿を示すのではなく、住宅 地の歴史や価值、意義が示されている。それは何のためのルールで あるかを居住者が理解できるようにするためであり、その上で修繥 や改善の方向が示される。財団の審査は年間約 900 件申請されてい るが、概ね許可される。それは、財団が申請を受け付けている大き な理由として、申請や許可というプロセスを通じて良好なデザイン へと誘導するためだからである。ゆえに、多くの申請は協議の結果、 許可される（表 7)。なお、デザインガイダンスは財団で常に内容を 見直し、改定を行っている注 25)。

C. 独自の規制地域

地区内には保全地区注 ${ }^{26)}$ がある。保全地区内では住宅の修繥や建 替えなどはより一層厳しい行政の審査を経る必要がある。さらに、 財団は保全地区以外に独自の制度として開発制限地区（Areas of
Development Restraint) を設けている。開発制限地区は、保全地 区とは別に、財団が独自に調和したデザインとレイアウトについて 価值があると定めて指定した地区である。開発制限地区内は保全地 区ではないことから、簡単な修繥や増築時に行政への計画申請や許 可を必要としないが、財団へは申請之許可を必要とする注 27)。

D. 修繥や保存のための補助金

適正な修絴が実施されるように財団は補助金を交付している。空 やドアの修繥には、工事総額の $30 \%$ あるいは 3000 ポンド以内、屋 根の修繥には、工事総額 $15 \%$ あるいは 3000 ポンド以内、前庭の生 け垣や柵、木の回復には工事総額 $50 \%$ の補助金を財団が出す。この 制度に基づいた実績は表 8 である。このように適切な修縖実施のた めに規制だけではなく、誘導策も実施している。

E. ガーデンシティヘリテージ賞

誘導策として、さらにガーデンシティヘリテージ賞授与を実施し ている。この賞は近年 5 年間中止していたが、再開することになっ た。修䋨により改善された不動産物件に賞を与えることで、不動産 所有者の改善意欲の促進と、改善のあるべき方向を視覚的に示すこ とを目指している。增築、その他の改築、前庭、そのほか非居住用 建物部門の 4 部門がある。

\section{(4)生活管理機能<第一機能>}

ハワードの思想にもとづき、不動産事業で得た収入はコミュニテ イに還元される。その主が第一と第五機能であり、両者は関係が深 い。第一機能では、防犯性向上として、車で地域をパトロールする 専門職員を雇用している。教育機能として博物館や農場経営がある。 高龄化対策としてワーデン付住宅、シェルタード住宅等を提供する。 (5)利便性向上機能 <第五機能 $>$

第五機能である利便性向上機能であるサービス提供では、ッーリ ストインフォメーションセンターの運営、ミニバスの運行、映画館 やホール、スピレラの運営、コミュニティ情報誌（'Insightと Spotlight）の発行等による地域の多様な情報の提供、スポーツクラ ブやレッチワースアートセンターの運営、多様なイベントの情報提 供、電動式移動補助装置（車椅子）の貸し出し、高齢者のための病 院経営、そのほか多様な地元組織（クラブ）の活動支援である。ク ラブへの補助金は、地域活動を行う新設組織に 1000 ポンド、総活動 費用の $50 \%$ までを補助する。地元にある 350 クラブの中から毎年補 助金を与える団体を選出し、活動を支援している注 28)。主に第一機 能は行政機能の補完、第五機能は市場の補完的役割である。

\section{4. 調査対象住宅の居住者属性と住宅地選択理由}

\section{1 居住者属性・住宅概要}

財団の取組みに対する居住者の評価を明らかにするために、調査 対象地区としてレッチワースガーデンシティでチープコテッジ地区 壮 29)（主は戸建て住宅）と、そこに近接する比較的新しい戸建て住宅 地区（隣接地区）を選定し、居住者意向を把握した。有効回収居住 者アンケート数はチープコテッジ地区が 127 、隣接地区が 38 である。 チープコテッジ地区では住宅の 7 割が 100 年以上の住宅である。 隣接地区では約 6 割が勧 50 年〜 59 年の住宅である。居住年数は兩 地区とも幅広く、住宅の築年数よりも居住年数の方が短いことから 中古住宅として購入した居住者が多くなっている。また、居住者は 自分の住宅の広さや敷地面積を知らない事例が多い。両項目ともに 
約 7 割の居住者は「不明」としている。そこで、住宅の大きさを寝 室数でみると、チープコテッジ地区で $3 \sim 4$ 、隣接地区では $2 \sim 3$ が 多い。対象住宅は戸建て住宅あるいは 2 戸 1 住宅で 8 割である。

家族構成は、大人一人が全体の $13.9 \%$ 、大人二人が全体の $39.4 \%$ であり、その他大人 $3 \sim 4$ 人家族もいる。結果、チープコテッジ地区 では 6 割で、隣接地区の 7 割で子どもがいない家庭である。

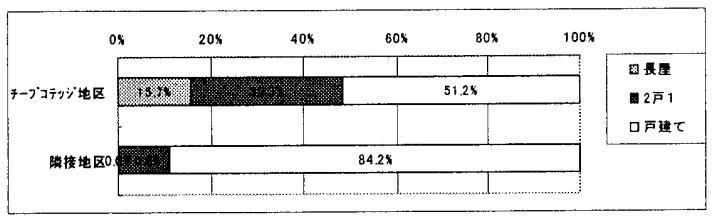

図 3. 調查対象住宅の建て方

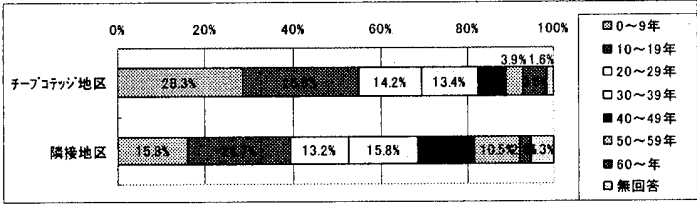

図 4. 調查対象居住者の居住年数

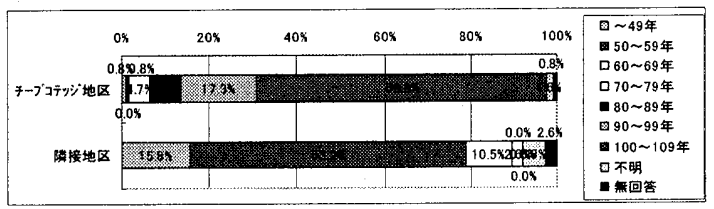

図 5. 調査対象住宅の築年数

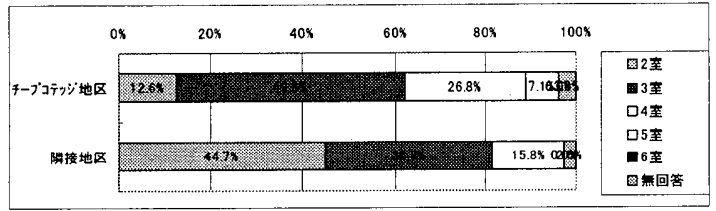

図 6. 調查対象住宅の寝室数

\section{2 住宅地・住宅を選んだ理由と住環境の評価}

住宅地・住宅を選んだ理由として、「住宅」「住環境」「立地」に わけてみると、「住宅」を評価して、入居をした人は両地区ともに多 い。全体的に、「住環境」を評価して入居した人は、チープコテッ ジ地区に多い。特にグリーンスペースや公園を評価している。店 や病院への利便性に関しては地区間に大きな違いみられない。当 初の計画ではレッチワース内で住み・働くことが想定されていた が、現在の居住者は職場に近いことは主な理由ではない。また、 特徴的であるのは、隣接地区では家族や友人がいることから転居 してきた人が約 4 割いることである（表 9)。

表9. 住宅地 - 住宅選択理由被数回答\%

\begin{tabular}{|c|c|c|c|}
\hline 分類 & 理由 & 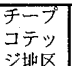 & $\frac{4}{8}$ \\
\hline \multirow{4}{*}{ 住宅 } & 住宅の間取りや大きさが気に入った & 53.5 & 44.7 \\
\hline & 庭が気に入った & 51.9 & 47.0 \\
\hline & 家のインテリアが気にいった & 28.3 & 23.9 \\
\hline & 家の価格が適当だった & 34.6 & 23.7 \\
\hline \multirow{3}{*}{ 住環境 } & 公園やグリーンスペースが気にいった & 53.5 & 34.2 \\
\hline & 景䫓が気に入った & 22.0 & 10.5 \\
\hline & 保全地区 あるいは部分的に保全地区があるが & 21.3 & 7.9 \\
\hline \multirow{3}{*}{ 立地 } & 店、病院、学校の便利がより & 33.0 & 34.2 \\
\hline & 家族や友人知人が质くにいる & 24.4 & 42.1 \\
\hline & 職場が近くか、便がよい & 22.0 & 28.9 \\
\hline その他 & 不動群を相統した & 3.1 & 2.6 \\
\hline
\end{tabular}

「住環境」 に関する評 価はチープ コテッジ地 区の方が全 体的に高い。 両地区とも に評価が低 いのは、行 政が行う道
路や通りのメンテナンスの状態や、住宅地の安全性や防犯性である。 住環境の総合的評価は、チープコテッジ地区では、「大変良い」が約 4 割、「良い」が約 5 割である。隣接地区注、「大変良い」が約 1 割、

「良い」が約 8 割である。このように住環境に対してはチープコテ ッジ地区の方が全体的に評価が高い（図 7)。

\section{5. 住宅地経営・管理方法の評価}

\section{1 財団による活動の評価}

財団が実施している活動のうち、「あなたにとって重要な活動は 何か」を質問した結果が表 10 である。最も評価が高いのは空間管 理・行政との協働機能であるグリーンスペースのメンテナンスであ る。財団が所有し、管理・運営する、グリーンウエイ、農場、博物 館、映画館、ホール、病院の評価が高い。博物館の評価は、特に 100 年の歴史があるチープコテッジ地区居住者で高く、病院とそこへの バスの評価は隣接地区で高い。全体的に、表 10 で設定した活動の項 目は、隣接地区の方がチープコテージ地区よりも評価は高い。家族 構成で、子どもの有無により評価に違いが見られ、農場、グリーン ウエイは子ぞものいる家では評価が高い。子どものいない家で評価 が高いのは、ホール、病院やそこまでのミニバス運行の評価が高い。

居住者の財団への総合評価は、行政との協㗢機能や空間管理機能 （第二.三機能）にあわせて、市場や行政の補完となる利便性向上 機能や生活管理機能（第一．五機能）と、さらに私権を制限する利 害調整機能（第四機能）の評価が総合して決まる。

第一二三五機能である行政や市場との役割分担・補完的機能につ いては居住者の評価は高い。そこで、財団による利害調整機能につ いての居住者評価をより詳細に把握するために、財団によって私権 をコントロールする手段となる「デザインガイダンスや管理規則」 についての考え方を把握した。「デザインガイダンスは住環境の維 持・向上に必要である」と、存在意義を認める人は、チープコテッ ジ地区では $40.2 \% 、 44.9 \%$ の人が必要だが内容の変更が必要」と 回答した。一方、隣接地区では、26.3\%の人が「必要」と回答し、50.0\% の人が「必要だが内容の変更が必要」と回答した。
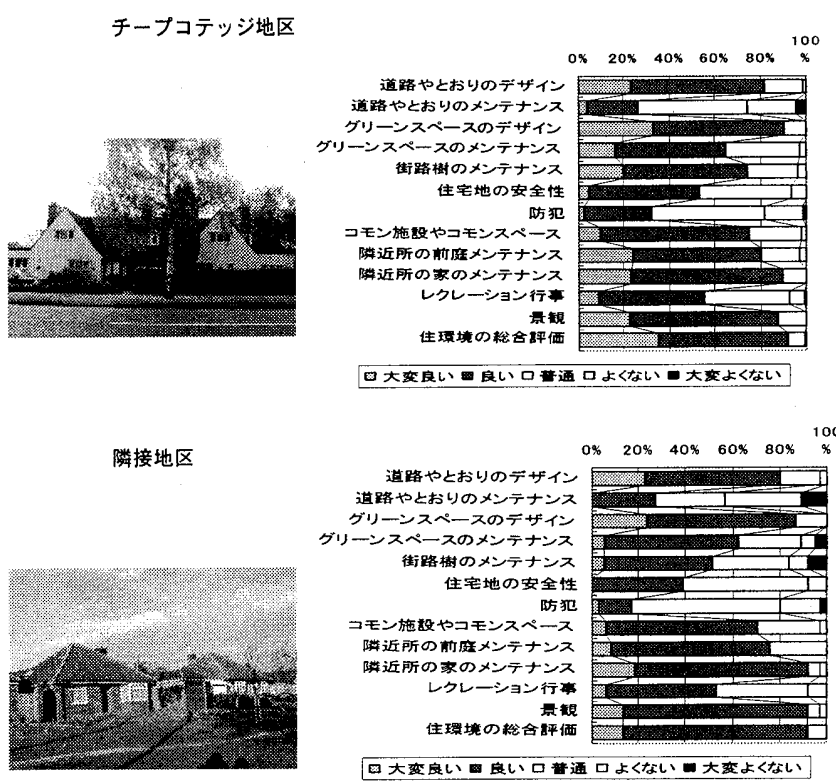

図 7. 住環境に対する居住者の評価 
管理規則に関しても同様の傾向が見られ、チープコテッジ地区で は、33.1\%の人が「住環境の維持・向上に必要」と回答し、 $28.8 \%$ の 人が「必要だが内容の変更が必要」と回答した。一方、隣接地区では、 $13.2 \%$ のが「必要」と回答し、 $44.7 \%$ のが「必要だが内容の変更 が必要」と回答した。

両地区ともに、内容の見直しも含めてデザインガイダンスが必要 だと考えている人は約 8 割、管理規則は約 6 割である。利害調整機能 に必要な管理規則やデザインガイダンスを「必要」と考えている人 は、隣接地区よりもチープコテッジ地区に多い。

表 10. 財団によるコミュニティへの還元活動の評価 䙉数回答 \%

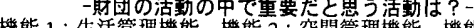

能 $3:$ 行政との協働機能、

\begin{tabular}{|c|c|c|c|}
\hline & 機能 & $\begin{array}{c}\text { チープコ } \\
\text { テッジ地区 }\end{array}$ & 隣接地区 \\
\hline グリーンウエイ & 2 & 42.5 & 60.5 \\
\hline グリンスペースのメンテナンス & 2.3 & 83.5 & 86.8 \\
\hline 家や庭の適切な修繥·改築実施のための活動 & 4 & 28.3 & 34.2 \\
\hline 修繯のための補助金 & 4 & 41.7 & 36.8 \\
\hline ガーデンシティヘリテーージ賞 & 4 & 26.0 & 15.8 \\
\hline 農場 & 1.2 .5 & 58.2 & 65.7 \\
\hline ヘリテージ博物館 & .2 .5 & 55.1 & 34.2 \\
\hline 映画館 & 2.5 & 71.6 & 68.4 \\
\hline ホール & 2.5 & 49.6 & 63.2 \\
\hline 病院 & 2.5 & 36.2 & 57.8 \\
\hline コミュニティ情報誌の発行 & 5 & 36.2 & 44.7 \\
\hline ツーリストイイフォメーション & 5 & 31.5 & 44.7 \\
\hline Eニバス & 5 & 7.1 & 31.6 \\
\hline クラブへの補助金 & 5 & 24.4 & 34.2 \\
\hline
\end{tabular}

\section{2 財団に対する居住者の総合評価}

居住者の財団に対する総合評価を把握した。チープコテッジ地区 では約 9 割の人が「財団の活動は住環境の維持・向上に重要な役割 を果たしている」(図8では「よい」と表示）と考元，隣接地区では 約 7 割である。

評価の相違は「管理組織の利害調整機能」への評価によるところ が大きい。居住者へのヒヤリング調查注 ${ }^{30)}$ 及びアンケート調查の自 由記入欄で「今後財団は住環境の維持・向上のために何をすべきか」 を問うた結果の主な内容は表 11 である。財団の活動を総合的に「よ くない」とする理由には、財団が行う利害調整機能を評価していな いことが大きい。よって、デザインガイダンスや管理規則を「必要 なし」と考えている人は、財団の総合評価を「よくない」と考えて いる人が多くなる (図 9)。前述したように財団の利害調整機能の評 価は、チープコテッジ地区の方が隣接地区よりも高いため、財団に 対する総合評価は、チープコテッジ地区の方が高くなっている。

表 11 に示すように、今後、財団の活動については、空間管理機能 の強化と、それに伴う行政との協働機能強化を望む傾向が強い。財 団と行政の協働による地域自治の強化が望まれている。

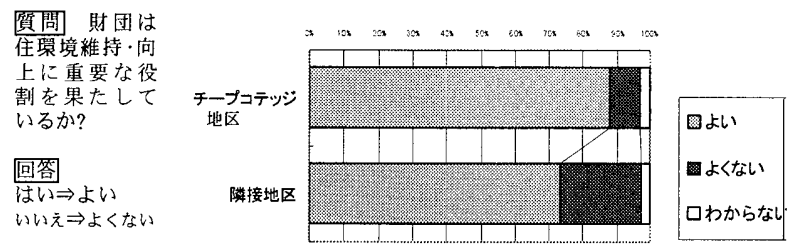

図 8. 財団に対する居住者の総合評価（地区別）

\section{6. 結論}

英国レッチワースガーデンシティをとりあげ、住睘境管理として 住宅地経営を行う財団の役割と体制、組織運営の財政基盤、財団へ
表 11. 財団は住環境の維持・向上のために何をすべきか 主な内容



図 9. 財団に対する居住者の総合評価（利害調整機能評価別）

の居住者評価を明らかにした。財団は、保有する不動産の運用によ る収入、それを基盤にした専門家や専従職員の雇用による専門家体 制を整備し、居住者の意向を踏まえ運営する。居住者の多くは財団 の活動を評価している。住環境管理の内容は、(1)グリーンウエイ、グ リーンスペース、農場などの他の住宅地にはない自然と共生した環 境の供給と維持の空間管理機能、(2)所有にかかわらず行政と協働し た公共空間の維持管理、(3)生活管理や利便性向上機能の実践、(4)管 理規則やデザインガイダンスによる住環境や街並みコントロールの 利害調整機能である。公共空間の管理については今後、居住者はより 財団が自治をもち、これらの空間の維持管理を行うことを求めてい る。このように行政や市場の補完機能を居住者は高く評価している。 一方、私権をコントロールする利害調整機能は居住者から概ね評価 されているが、住環境への関心が低い居住者には不満も見られる。そ れは、一つには行政との役割分担が明確になっていないことがある 注 31)。もう一つには、住環境の管理組織は、多様な機能をもち、か つ利害調整機能も実施することで、市場や行政サービスの単なる補 完でなく、これらが実施できない行為を行っていると、居住者が理解 できるが、専門会社型管理運営であることから、日常的な管理への 居住者参加の機会は少なく、住民の住環境管理への関心に開きがあ るからである。利害調整機能が機能するには、デザインガイダンス や管理規則が地域のニーズにあっていることに加え 専門会社任せ にせず、居住者の関与も必要である注 32 。

以上、レッチワースの事例を参考にすると、わが国においても専門 会社活用方式として大きく二つの可能性、一つは地域密着不動産管

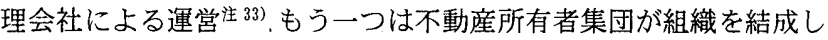
(例えば住宅所有者による管理組合)、専門家·専門会社雇用による運 営が考えられる。住民の主体性の維持、公との役割分担、住宅地経営 として経済的に成立する条件等、実践には詳細な検討が必要である。

謝辞 : 本研究を進めるにあたり、レッチワース財団のケニ一局長に は幾度も調査にご協力をいただいた。芝浦工業大学松下潤教授には 調査の助言を、明海大学中城康彦教授には 2005 年 3 月調査に、加藤 邦彦氏（国土交通省土地・水資源局土地政策課）には2006 年 1 月調 
查に同行いただき、多くのご指導をいただいた。アンケート調査実 施には茂木崇宏・中馬義人 (当時明海大学不動産学研究科大学院生) 両氏の協力を得た。レッチワース居住者からは暖かい励ましと多く の回答を得た。ここに記して関係者皆様に感謝の意を表します。

注

注 1) 住環境管理の行為を、利用者特性に着目した対象空間の分類と、行為の性 質加 5 機能に分類した。近年、生活管理機能(第一機能) は、行政サービ ス、市場サービスのみで提供が困難となってきている。空間管理機能(第二 機能)怯、マンションのようにコモンスペースをもつ住宅の增加が、必要性 を高めている。行政との協働機能(第三機能) は、公園や公民館、道路の管 理等があるが、地域で行うことで、效率的、経济的に実施でき、かつ地域の 実情にあった方法が可能となっている。利害調整機能 (第四機能) は、例え ば隣接住宅の建替えに伴い、建物の高さや壁面後退の不足から近隣住宅が 圧迫感を感じるなどがある。これらの行為は法律に違反していないため行 政も関与できない。市場に任せていると、住環境悪化を阻止できない可能 性がある。そのため、住民が合意した住環境の目標像をつくり、共有し、 それを実行する(私権の制限も含む)ことが必要となっている。利便性向上 機能 (第五機能) は、高齿化や少子化等も含め、地区の要求が多様化し、それ を適切に把握し実践する地域サービス機能向上への期待が大きい。

\begin{tabular}{|c|c|c|c|c|c|}
\hline 空间 & 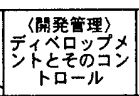 & 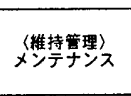 & 紧学䉕理〉ト & 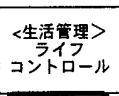 & 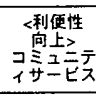 \\
\hline 公共架间 & & 第三機能 & & & \\
\hline 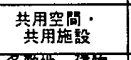 & & 第二椎能 & & 籍- & 籍吾 \\
\hline 客教地・建物 & 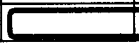 & 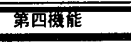 & & & \\
\hline
\end{tabular}

注 2) HOA (homeowners association：管理組合）による管理方法やその方 式のわが国への導入の検討は、文献 7.8.9.10など。

注 3）文献 1 6、13.14.15

注 4) 文献 10。日本のマンションでは区分所有法、戸建て住宅地では区分所 有法の団地規定の準用や法にもとづかないケースがある。戸建て住宅地で 共有物がない場合には組織継続の必要性が低く、消隇する傾向にある。な お、米国の HOA は州法に基づく

注 5) 最近ではマンションの共用部分として店舗を持ち、管理組合が貨貸料収 入を得るものや、戸建て住宅地でも貸し駐車場を運営し、使用料収入を得 ているケースが見られる

注 6）ガーデンシティ、ガーデビレッジ、ガーデンサバーブの住環境管理方法 仕文献 11 で報告している。機能限定型は、組織は利害調整機能が中心であ るが、私権をコントロールする権限をもたない夕イプである。この場合は 会貝からの管理費が主な収入で、組織の構成員は主に居住者である。

注 7）文献 1〜6、13.14。

注 8）英国では土地と建物は一体の不動産である。不動産保有権は大きくはり 一スホールドとフリーホールドに分れる。フリーホールドとは「自由土地 保有権」であり、わが国の所有権に近い。リースホールドは「貨借土地保 有権」と訳され、期間限定利用権で、長期のものはわが国の借地権に近い。 注 9)レッチワースでは、公社が管理していた時代は 55 歳以上で 10 年以上居 住した居住者にはフリーホールドに移行する際の俩格の支払いを、転売時 もしくは名義人やその配偶者が死亡時まで猶予し、その間の利息も低く押 さえられていた（文献 4 p.48）

注 10）敖地面積は幅広く、地区では 400 $600 \mathrm{~m}^{2} か ゙$ 約 6 割である。今回のアン ケート回答者住宅では、 $2399 \mathrm{~m}^{2} ; 7.8 \% 、 \sim 599 \mathrm{~m}^{2} ; 7.1 \% 、 \sim 799 \mathrm{~m}^{2} ; 3.9 \%$ 、 $999 \mathrm{~m}^{2}: 3.1 \% 、 1000 \mathrm{~m}^{2} \sim: 11 \%$ あ゙る。隆接地区も户建て住宅地で敷地面積が 比較的小さい地区で、今回のアンケート回答者住宅では、 $399 \mathrm{~m}$; $15.8 \%$ 、 $599 \mathrm{~m}^{2} ; 10.5 \% 、 \sim 799 \mathrm{~m}^{2} ; 0 \% 、 \sim 999 \mathrm{~m}^{2} ; 2.6 \% 、 1000 \mathrm{~m}^{2} \sim ; 10.5 \%$ である。

注 11）文献 4 によると、株式会社の株の配当がよくなり、ホテルヨーク社に 株式会社が買収された。1960 年にはこの状況に対し、住民集会「レッチワ 一スを救おう」が開かれ、公共機関として新しく公社が設立された。

注 12）公社から財団に 1995 年の移行した理由は、文献 3.4 によると、公社時 代の経営体制を效率化する、透明性を確保する、また住民の意向が反映で きる体制をもつことで、民間団体になることが望まれたからである。こう して、経営主体が公的機関から民間機関に変化したことは、文献 2 では「1995 年、信阡公社の事業は公的権力をもたない、慈善的性格の産業共済会に移 管したほうが地域の利益にかなうとされ、・解散された。サッチャ一保守 党政権による一大改革路線の影響によることはまちがいない」とある。公 的機関と民間機関の実際の運営の相違は、財団のケニー局長によると、「公 社と財団では機能はほぼ同じである。最大の違いは運営の仕方であり、公 社では理事を選び、財団ではガバナ一を選ぶ。公社時代には中央政府から 公社役貝が任命されていたが、現在はいない。こうした点が大きく違う」。 注 13)1995 年法では 1962 年法による公社を廃止し、その趣旨は財団に引き継 がれ、引锞ぎ方法、事業や㕍用の継続、会計、費用負担方法が示されている。 注 14）部門は 6 であるが、職員は保育・看護、旅行・観光、山林管理、仕出サー ビス、運転、農業、環境計画、調查、広報、金融等の多様な技能を持つ。 注 15) シネマ関係、農場関保、IT サービス供給、社会住宅供給・管理（ハウ ジングアソシエーションとしてハウジングコーポレーションに登録)、ツー リストインフォメーションセンターやスピレラやホールでの飲食サービス や土産販売のサービス会社をもっている。

注 16) ガバナー選出には三つのカテゴリーがある。(1)elected ; 5 年毎にレッ チワースガーデンシティで登録された有権者による無記名投票で決める。 2005 年は 16 名の候補があり、当選者 6 名の内、2名が新人で 4 名が再選て ある。16名に投票された合計票数は 22488 票であり、レッチワース居住者 の関心が高いことが分かる。75 歳が定年であり、立候補者は18歳から70 歲であること。(2nominated; 30 のクラブ等から推蔦される。(3)general; ビ ジネスや金融、不動産、商業等の事業技能をもつ人が望まれている。レッ チワース居住者でなくてもよいが、実際にはレッチワース居住者が多い。
注 17）圸域の住民活動団体で例えばコミューティアソシエーションスポー ツクラブ、フットボールクラブ、ゴルフクラブ、ボールクラブなどが 350 ある。 注 18）規定（財団のルール）には、財団の名称、目的、ガバナーの選出方法、 総会、運営委員会の選举の仕方や権限等が記載される。ここで全居住者に 対して少なくとも年に 1 回恃居住者総会を開くことが規定されている。

注 19）運営委員は general から6 名、その他行政からの2 名で構成される。 再選は可能である。また 75 歳になれば退任するルールとなっている。 注 20) 文献 3 p. 147

洋21）ただし、ゴルフコースだけは商業ベースで営業を行っている。

注 22）レッチース中心部に大型スーパーを誘致した。その際、財団はリー スホールドで貸していたカレッジ（当時非利用）の敷地を利用した。財団 は所有する土地の利用を誘導し、事業が円滑に推進できるようにしている。 注 23) カベナントには消極的内容 (不作為) と積極的内容（作為）があり、 前者壮禁止事項で、後者は何らかの作為や出費を義務づけるものである。 カベナントは新しい所有者も拘束するが、それは不作為のものだけである。 また、登録しないと対抗要件とならない。ガベナントを登録しても、フリ 一ホールドである場合は、「建物をしつかり管理すること」といった作為の カベナントの内容が引き継がれない。そこで管理規則が必要となる。

注 24）レッチワースの地区内にある 2 简所のハウジングアソシエーション供 給の団地では管理規則が適用されない。レッチワースでは管理規則は制定 以来一度も内容の変更をしていない。また、管理規則の中には前庭の維持 管理が適切にされない場合の財団の強制執行権が規定されているが、現実 には一度も執行されたことはない。

注 25） $4 \sim 5$ 年周期で内容を見直している。

注 26) 保全地区（Conservation Area） 怯、糜史的または建筑的に特別の価值 を持ち、その特性を保全・向上することが望ましい地区を指定する制度で ある。坝区内で、建造物の取り㯰しや增筑、外観の変更等にすべて許可が 必要となる。広告規制、木の保全も強化される。レッチワースでは 1974 年 に地区中心部及び 1914 年以前建設の主要な住居地域が指定された。また登 録建造物 (Listed Building) も調查対象地区内にある。登録建造物制度は建 筮的又は歴史的に重要な建物を指定登録し、その建物の取壊し、改策、改 変に対する規制を強化する仕組みである。一般的に開発行為に該当しない と考えられている小規模な建物の外観の変更も、申請と許可が必要となる。 注 27) 開発制限地区の一部が保全地区にくみこまれ、保全地区がレッチワー ス内で広がっている。レッチワースでは、管理規則の適用地区、保全地区、 独自規制地区（開発制限地区）の関倸は以下のとおりである。

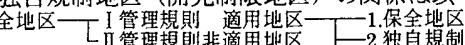

\section{海全地区でも開発制限地区でもない地区}

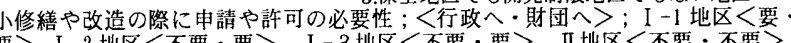
注 28) クラブなどの活動の内容、メンバーの数や年齢、活動の頻度・回数、 会費、年間収支などを申告し、補助金を申し込む。

注 29）1905 年にレッチワースの名を広く一般の人に広報するために企画され た展示会である。1 件 150 ポンドの住宅が多様な建築家によって設計された。 現在は二の地区保全地区となり、登往建浩物に指定されている住宅もあ る。一方、比較のために選定した新しい地区は、第 2 次世界大戦後に開発 された地区で、保全地区ではなく、登録建造物もない。

注 30) アンケート回答居住者のうち、財団の総合評価を「よい」「よくない」 と回答したそれぞれの居住者に対してヒヤリング調査を実施した。

注 31）居住者は建筑に関する申請や許可を 2 重に取らなければならない。

注 32）他住宅地ではみられるような管理問題の解消や予防を居住者が主体性 に取組む体制はあまりみられない。例えば、他住宅地では住民が主体とな

って防犯の取組みやデザインガイダンスを居住者が守るための㤵発的活動 などを行っている(ブレンサムやウエルウィン等 文献 11) が、レッチワー スでは自主的活動があまり見られない。

注 33）建築ストック社会に対応した不動産業として、従来の開発型から転换 し、地域の不動産を所有・管理した不動産管理会社が、地域住民の意向を 踏まえて、地区内の建筑のコントロールをはじめとし、多様なコミュニテ 施設の提供・運営、居住サービスの提供を行う形で住宅地を経営する力 法である。一方、不動産所有者型は、組織が不動産を所有・経営し、その収 入を基盤とし、地区内の建築コントロールを行う尃門家を雇用する等、専 閶家・基門会社による支援体制をつくり、総合的に住環境管理を実践する 方法である。

\section{参考文献}

1) 西山康雄 : アンウィンの住宅地計画を読む 彰国社 1992

2) 菊汹威: 田園都市を解くーレッチワースの行財政に学ぶ 技報堂 2004

3 ) 西山八重子: イギリス田園都市の社会学 ミネルヴァ書房 2002

4 ) 中井検裕 : レッチワース田園都市の財政状況の歴史的変遷の分析 2005

5) 齊木崇人: 最初の田園都市・レッチワース 造景 16 号 P. 139〜167 1998

6) 東秀紀他：明日の田園都市への誘い 彰国社 2001

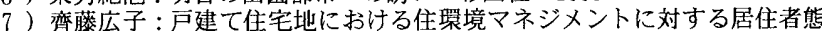
度一戸建て住宅地におけるHOA導入についての居住者評価一日本建築 学会計画系論文集第 583 号 P. 127 133 2004. 9

8 ）齊藤広子：米国カリフォルニア州のC I D管理におけるHOAの役割と それを支える法制度一 住み手主体の持続型住環境管理システム構筑の ための研究一都市計画論文集 39 2004.11

9 ) 齊藤広子: 户建て住宅地にお污る居住地マネジメント組織としてのHO A 導入のための課題 都市住宅学 39 号 2002. 11

10 )齊藤広子:日本におけるHOA型住環境マネジメント組織の実態と課題 都 市住宅学 43 号 2003.11

11 ) 弯藤広子・中城康彦: 英国におけるガーデンビレッジ・ガーデンシティ ガーデンサバーブの管理組織の役割 都市計画論文集 41 2006.11

12 ) Mervyn Miller: Letchworth the First City $2^{\text {nd }}$ Phillimore 2002

13 ）井原満明・村上暁信：田園都市レッチワースの地域経営-維持管理そし て創造にむけて-地域開発 P. $41 \sim 49 \quad 1999.5$

14）都市農地活用センタ一: 中国・英国における定期借地制度 2003.3

15 ）国土交通省：農住組合の新たな活用方策檢討調查報告書 2003.3 